\title{
"You can('t) let go now": Mystery boxes, quantum readings and very bright lights in Lost
}

\section{Florent Favard}

\section{(2) OpenEdition \\ 1 Journals}

\section{Electronic version}

URL: http://journals.openedition.org/tvseries/1738

DOI: 10.4000/tvseries. 1738

ISSN: 2266-0909

\section{Publisher}

GRIC - Groupe de recherche Identités et Cultures

\section{Electronic reference}

Florent Favard, " "You can('t) let go now": Mystery boxes, quantum readings and very bright lights in Lost», TV/Series [Online], Hors séries 1 | 2016, Online since 01 October 2016, connection on 19 April 2019. URL : http://journals.openedition.org/tvseries/1738; DOI : 10.4000/tvseries.1738

This text was automatically generated on 19 April 2019

\section{(c) (1) () $\Theta$}

TV/Series est mis à disposition selon les termes de la licence Creative Commons Attribution - Pas d'Utilisation Commerciale - Pas de Modification 4.0 International. 


\title{
"You can('t) let go now": Mystery boxes, quantum readings and very bright lights in Lost
}

\author{
Florent Favard
}

1 Alone in the night, John Locke, the man who once worked for a "box company", is banging against another, bigger box, buried in the middle of the jungle. A young man, Boone, just died because he trusted him. Now Locke is asking why. "I've done everything you wanted me to do, so why did you do this to me?". For all he knows, it could be empty, and worse - his biggest fear - devoid of any meaning. Perhaps Locke is afraid he does not have a destiny. He is afraid he just got a young man killed for nothing. At this precise moment, a light goes on inside the hatch; Locke's eyes shine with wonder and hope.

2 Thus ends Deus Ex Machina (S01E19), an episode that played on every variation of faith and trust, from Boone following Locke, to Locke's mother claiming he was "immaculately conceived", Locke trusting his conman of a father, Sawyer getting played by Jack, up until that fateful moment when the light teases the audience and asks for a little more time, just a little more time, before opening the mystery box.

3 More than five years later, in "Abed's Uncontrollable Christmas" (S02E11), a special, stopmotion episode of the reflexive sitcom Community ( $\mathrm{NBC}>\mathrm{Yahoo}, 2009-2015)$, one of the characters, Abed, is looking for "the meaning of Christmas". With the help of Pierce, a member of his study group, he breaks into Santa Claus' workshop, only to find a box labelled "Meaning of Christmas", which contains another box labelled "not quite yet", and then another, "keep going", then another, "almost there", until...

ABED. It's the first season of Lost on DVD.

PIERCE. That's the meaning of Christmas?

ABED. No, it's a metaphor. It represents lack of payoff. 
First aired on December $9^{\text {th }}, 2010$, this episode encapsulated in one joke the zeitgeist of the hour, which quickly became the zeitgeist of the decade: the end of "cult blockbuster 1 " TV series Lost (ABC, 2004-2010) was a disappointment for many people who thought it did not deliver what was once promised: answers and meaningfulness. Some of them just brushed it off over time. Others kept banging against the hatch, with no light in sight.

This paper is about Lost $^{2}$. It is also about its one-of-a-kind production and fractured reception. It is about its passionate study by academics - on a level not dissimilar with other "series-as-studies" such as Buffy Studies or Doctor Who Studies.

This is not an attempt to describe what "went wrong", or to defend what "went right". Within a contextualist, narratological frame, this paper follows the philosophy of "storyology" or, as Marie-Laure Ryan puts it, "the study of the logic that binds events into plots", one more often found in the practical discourse of "scriptwriters" and "How To manuals", than in shades of narratology often too detached from the pragmatic side of what is "good" storytelling in a given cultural context ${ }^{3}$. This work also draws from possible world theory applied to fiction to get a closer look at the fictional world created by the writers, a world which the viewers "reconstruct" using the "set of instructions", the text that serves as a "semiotic channel" between our world and the possible worlds in narratives ${ }^{4}$. I am interested in the "making of meaning" - a meaning that is "not found but made ${ }^{5 "}$ - among its fractured audience, following David Bordwell rather cognitivist distinction between "comprehension" ("referential and explicit meanings") and "interpretation" ("implicit and symptomatic meanings"), as well as the discursive dyad lecture en progression - the functional "reading in progress", following the events of the plot - and lecture en compréhension - the more hermeneutic "reading in understanding" proposed by Bertrand Gervais?

With these theoretical frames in mind, I want to take one last hike along the shores of the island, then go up to the bamboo forest to take a look at some aspects of the narrative structure of Lost that may have been catalysts for its fractured reception. After replacing Lost in its context, I will question the lurking shadow of Abrams inside the text, before examining its narrative closure through the configuration of the Heart of the Island and the flashsideways.

\section{Narrative complexity, teleological structure and fractured reception}

9 There is no single reason why Lost was so polarizing from beginning to end. Yet, one obvious key factor is the heavily serialized, teleological configuration of its narrative.

Back in 2004, Lost was a revolutionary but logical step among increasingly, "narratively complex" television series that "[redefined] episodic forms under the influence of serial narration". Its long-term plot is spread across entire seasons, and the series as a whole is driven by "macro-questions" that point to its eventual narrative closure - where "closure is a matter of concluding rather than merely stopping or ceasing [...]". Noël Carroll, drawing upon Aristotle, sees closure as completeness, correlated "with answering all the presiding macro-questions that the story has proponed ${ }^{10 "}$, but admits that it is "not a 
feature of all narratives ${ }^{11}$ ". It certainly isn't a predominant feature of American television series, since they "[lack] a crucial element that has long been hailed as of supreme importance for a well-told story: an ending", and follow what Jason Mittell describes as an "infinite model of storytelling" driven by ratings and economic value ${ }^{12}$. The closure promised by Lost was first and foremost a way to launch the story towards an infinity of possible outcomes, until it became an actual pledge for three more years before the end date, during its third season.

11 The narrative teleological structure is driven by two macro-questions - or, as I will call them from now on, major questions. The first generates suspense. Lost, taking as a starting point a classic "robinsonade", plays with the fate of the survivors of flight 815's crash on an unknown tropical island: will they ever be rescued? The second major question is bound to elicit curiosity: what is this island, what is its history, its geography, and why is it such a fascinating and dangerous place? The series adds surprise (that is, its famous twists and cliffhangers) to complete the set explored by narratologist Raphaël Baroni ${ }^{13}$, generating tension on a massive scale measured in months and years.

Along with Lost and its intricate six seasons plot came another revolution just as important when considering its polarizing reception: Henry Jenkin's convergence culture, "where grassroots and corporate media intersect ${ }^{14}$ ", where culture became (all the more) participatory thanks to web 2.0, and the collective intelligence of thousands of Mittell's "forensic fans ${ }^{15}$ " allowed the viewers to crack even the most complex alternate reality game. This is the culture that expanded Lost into a vast and rich transmedia universe ${ }^{16}$, sparking the creations of wikis and never-ending water cooler conversations on forums and social networks.

13 It also allowed showrunners to gain even more visibility through their online presence, with one major setback in the case of Lost's Damon Lindelof and Carlton Cuse: the two waves of harassment against Lindelof's Twitter account. The first roared right at the end of Lost, with Lindelof receiving tweets along the lines of "You're a dirty liar. You never knew, you made it all up, you betrayed us all. You betrayed me and I hope you rot, motherfucker [sic] ${ }^{17}$." The second hit soon after Breaking Bad (AMC, 2008-2013) aired its critically acclaimed and non-polarizing final episode, and it sounded like "Hey @DamonLindelof, that's how you answer all the questions and close all the loose ends. \#asshole [sic] \#GoodbyeBreakingBad ${ }^{18 "}$. These vitriolic tweets, these "discourses of rejection ${ }^{19}$ ", ultimately led Damon Lindelof to close his Twitter account on October $14^{\text {th }}$, $2013^{20}$.

Indeed, the situation was not anything new. As Rebecca Williams explains, "the disappointment and disillusionment of many Lost fans had begun years before the final season and offers perhaps one of the most vitriolic examples of antagonistic fan-producer relationship ${ }^{21}$ ". Certain fans felt betrayed by the writers, whom they assumed had a masterplan: the focus on characters heavily demonstrated by the last season was perceived as a cover-up to hide the plot holes; Williams links the dichotomy characters/ mysteries to "issues of genre and also to a more subtle process of gendering specific readings of the show ${ }^{22}$ ". Facing those "anti-fans" were the fans who enjoyed the finale and the series as a whole, trying to cope with the loss of a show that meant everything for them $^{23}$. As a participant observer of French-speaking forum Lost-island ${ }^{24}$, I noted the same dichotomy, often explicitly verbalized by the users themselves, between the "theorists" and the "characters fans"; a dichotomy fully achieved when Lost aired its final episode ${ }^{25}$. 

sides of Lost as a text: Roberta Pearson examines the slow transition between the former, aiming at a "cult" niche market, and the latter, designed for a broader audience ${ }^{26}$. Ivan Askwith explored in details the way Carlton Cuse and Damon Lindelof interacted with the fans, promising answers, swearing they had a masterplan ${ }^{27}$, when in fact it is almost impossible to conceive one in the television industry, barring other alleged exceptions such as Babylon 5 (PTEN>TNT, 1993-1998).

Pearson's Reading Lost, in which one can find the last two quoted papers, is an interesting piece for the historiography of Lost Studies: Pearson, Askwith and others observe the series at the middle of its initial broadcast, drawing from promotional and authorial discourses to explore the "reception in progress" of the series, before academics came to see the text as a whole, retrospectively (perhaps losing sight of that "reading in progress" aspect). The portrait they give us is that of a series at a turning point, its three-years-andan-end-date deal promising closure and a way for both the mysteries and the characters to meet a fitting denouement, after what seems to be a critical and muddy era for the show in terms of rhythm.

The initial, in progress reception was perceived as "ludic storytelling", with forensic fans being able to "play for plot" ${ }^{28}$ both with the episodes and with transmedia content such as alternate reality games. Even the quest for spoilers was not so much a way to compete with the writers than a means to assess better, playful control over their reading of the unfolding story ${ }^{29}$. Among others, Martial Martin underlines the limits of playing with, and poaching, the text, noting that along the years many fan theories were rejected not only within the text, but through declarations by the writers who asserted their control over the text ${ }^{30}$, another factor leading to the "antagonistic" relationship between fans and producers and to the divisive reception of the final season explored by Rebecca Williams.

Lost promised answers and closure in an era when fans had the ability to hold showrunners up to their word, and this is why it has been a fascinating case of study along the years. Yet, other narratively complex television series play on what I call a closure pledge - see for example the quest for Earth in Battlestar Galactica (Syfy, 2003-2009), or the non-linear sitcom How I Met Your Mother (CBS, 2005-2014) which made the promise of an ending in its very title ${ }^{31}$. What is more specific to the island-driven show is something hidden in plain sight, in its very DNA: J. J. Abrams.

\section{The return of J. J. Abrams' mystery box}

19 I know what you may be thinking: "please, enough with the mystery box".

20 Of course, Abrams himself left the show early in its first season to work on Mission Impossible III (2006), leaving in charge Damon Lindelof, with whom he co-created the hit TV series. Lindelof was quickly assigned a co-showrunner, Carlton Cuse, and the two became the double-headed Hydra at the helm of Lost. It would not be the last time Abrams created a high-concept TV series before leaving it in the hands of others: four years later, Fringe (Fox, 2008-2013) would be the next.

21 Yet, fan and critic discourses still associate Abrams with series and movies supervised by Bad Robot Productions ${ }^{32}$ - which Abrams founded - and this is for a good reason: even away from the writing room and the set, the producer still keeps a close eye on his projects, being particularly supportive in interviews, and a major support when Fringe

TV/Series, Hors séries 1 | 2016 
and Person of Interest (CBS, 2011-2015), in-house productions, needed one last season to conclude their own long-term plots. His "long shadow", that is, the "producer-as-paratext 33" that is part of his ethos, can be very influential; Jonathan Gray showed how the niche audience of Abrams' Alias (ABC, 2001-2006) "was able to propose and share a series of viewing strategies and expectations with the broader, more mainstream audience that greeted Lost in its first season ${ }^{34 "}$. That is, fans of science fictional spy-thriller Alias shared advices on Abrams' writing philosophy and obsession with the construction of a "mythology", a complex ensemble that cannot be reduced to the main plot: it distinguishes itself from the "canon" by being oriented towards the future, generating a complex and shifting fictional encyclopedia that underlines its incompleteness, as well as carrying the thematic and symbolic aspects of the narrative $e^{35}$.

As Lindelof himself explained,

[...] Hey, if we put it on the air, and we're like, "there's a polar bear in the jungle", somebody better know where the fuck [sic] that polar bear came from. Like, that's all there is to it. So that pressure was enormously debilitating. And at that point, I was thinking, J. J. is now creating a very good case for plausible deniability. When the torch-wielding mob shows up at his house and they're like "where does the polar bear come from?", he could be like "I'm working on Mission Impossible, go to Damon ${ }^{36}$."

Lindelof repeatedly comes back to Lost's first season in interviews, highlighting both the incredible bet that was the series and the Abrams hype that fell on his shoulders, with fans already pressing for answers, because of the concept at the foundation of Lost and its fictional world: the "mystery box", a creative frame explored by Abrams in a TED talk in March 2007. Fascinated by "infinite possibility", Abrams values "mystery [as] the catalyst of imagination" and sees stories as mystery boxes, insisting on the fact that there is "what you think you're getting, then what you're really getting ${ }^{37}$." But audiences might read mystery differently, especially in a fictional world that quickly underlined its internal interconnectedness ${ }^{38}$.

Ivan Askwith distinguished two sorts of questions in Lost: those turned to the past (such as the nature of the Island) and those turned to the future (the most important being: will the castaways ever leave the island?); of the two, those concerning the past should be predetermined, he assumes, since they "become the basis for understanding the present" of the fictional world". Jason Mittell operates a similar distinction between "narrative statements" (raising questions about the future) and "narrative enigmas" (raising questions about the past $)^{40}$. This distinction derives from a similar thinking as Baroni's curiosity and suspense, generating narrative tension that is either directed at what happened or what will happen. Askwith's "pre-determined questions" could be read along structuralist narralogist Gérard Genette's "regressive causality", Anton Chechov's famous gun or even the completeness of action described by Aristotle: the idea that an author should work the plot from the end (and thus know in advance all the revelations about the past); a paradigm that, according to Marc Escola, is "regularly presented as a poetic law (the very logic of fiction writing), [...] when in reality it derives from a hermeneutic frame, while narratology's ambition is only to be descriptive ${ }^{41}$."

The detailed account of the creation of Lost by writer Javier Grillo-Marxuach (who participated in the initial think tank assisting Lindelof and Abrams, before serving on season one and two) seems, on the one hand, to validate this "pre-determined" thinking, 
through the brainstorming around "the hatch" (the Swan Station), which GrilloMarxuach links to Abrams mystery-box motto:

JJ was more than happy to punt the decision as to what would actually be inside the hatch to the writers' room because of his deeply felt conviction that the mystery was as good a journey as the reveal and would be so tantalizing it would keep the audience clamoring - even if the subject to be eventually revealed was not forethought. It was at that point that I first heard Damon articulate [...] the one hard and fast rule that he lived by for the entire first season. He would not put anything on screen that he didn't feel confident he could explain beforehand ${ }^{42}$. writing on his part, since his paper deals primarily with producer's discourse and audience reception: the showrunners of Lost, he claims, were the first to promise a story with a beginning, a middle and an end, and were then overwhelmed by the audience's assumptions that they weren't making up at least half of the plot; Askwith also underlines the perils of "regressive causality", in that audiences do not seem to value "making it up" as much as "planning it up", reading television series as they would a book or a movie (a comparison that critics feed with concepts like quality, novelistic television). The theorist fans might have seen the mystery box as already full of determined, upcoming narrative elements, when in fact it was full of potentiality, ready to be adapted. Lindelof himself also underlines the paradox of Lost reception: fans wanted their input to matter and, at the same time, they wanted the writers to have a definitive masterplan ${ }^{44}$. The reflexive killing of characters Nikki and Paulo in Exposé (S03E14) has been hailed as the perfect example of Lindelof and Cuse course-correcting the narrative to please the fans.

28 I have noticed that the metaphor of the magic box is also heavily quoted by my fellow academics in informal conversations, whenever I bring Abrams' mystery box to the table. First mentioned by Ben Linus in "The Man from Tallahassee" (S03E13) and then debunked by him as a mere "metaphor" in "The Brig" (S03E19), the magic box is read as a direct reference to the "magic mystery box" that Abrams brought with him on his TED conference, claiming he had never opened it. Ben uses the magic box metaphor to mock Locke, a character that could be perceived as a proxy for the theorist fans since he believes there is a reason for the presence of the castaways on the island: they have a "destiny", and somewhere, someone (Jacob) has a masterplan for them.

Yet, if this metaphor was intended to deflate mystery-box readings of the series, I would argue that it only added fuel to the fire. One could even go as far as acknowledge the continuous presence of mystery boxes long after Abrams' actual departure: Locke's coffin, Locke's box brought by Ilana, or even the monster itself, a seemingly magical creature which holds within itself "whatever you want to be in it" by being polymorphous and able to mimic lost relatives and animals.

30 Even more, Abrams' conception of the mystery box is not teleological since, in his TED conference, he values the "open-endedness" and "free-flowing creativity" that 
characterizes television writing ${ }^{45}$, aspects that were emphasized over the years by Cuse and Lindelof, and by Javier Grillo-Marxuach in his "Lost Testament". Whether Lindelof and Cuse gave answers or not may not even matter: the game was rigged from the start for at least a sizeable part of the audience, and the viewing strategies seeded by Abrams and his long shadow may be partly responsible for its fractured reception. Lindelof and Cuse, in the early seasons, ended up playing with Abrams' deck in a poker game with the audience, before rallying for the open, character-driven conclusion of the series perhaps the only way to stay true to Abrams' and Lindelof's initial vision.

My point is that we should not so easily dismiss the influence of Abrams' mystery box even in later seasons, both in the text and in its reception; and we should not associate the "mystery box" concept solely with what the theorist fans have made of it (even if what they have made of it is of critical importance to understand their reading of the series). The goal of the mystery box is to encapsulate infinite possibility; it is also important to note that this philosophy of writing cares for the characters and cannot be reduced to plot. For Abrams, the wonder of the mystery box also comes from the distinction between "what you think you're getting" and "what you really get": he exemplifies Jaws (Spielberg, 1976) as a movie in which the audience is expecting scenes of shark attack - they want to see the mysterious shark lurking in the waters; but the movie is also about "a guy who is sort of dealing with his place in the world - with his masculinity, with his family, how he's going to, you know, make it in this new town ${ }^{46}$." Abrams may not appear to reinvent the wheel here; but the mystery box is not about proposing something new; it is rather a new way to look at classic storytelling, with a focus on the potential of a story.

Here, I argue that reading the mystery box as a strictly hermeneutical mode of writing misses parts of Abrams' philosophy, parts that Lindelof and Cuse put to use, giving Lost other Bad Robot typical elements such as a focus on inter-generational groups and families. The series' mythology, when not reduced to the main plot and explored as a more complex way of reading the text (including characters, thematic and symbolic aspects), may be closer to the "mystery box" concept than what Abrams' departure seemed to indicate: his spirit still roamed around the island long after his leaving of the show, possibly until "The End".

As Abrams would say, there is what we thought we were getting (a mystery to be explained) and what we got (a spiritual, heartfelt parable on human existence). Lost is, in a way, the ultimate mystery box.

\section{The island that was both fantasy and science fiction}

Whether they were planned in advance, at the time of the three-year renewal, or left unanswered in the writing room until the last possible moment, many answers to the mysteries of the island are given to the audience during the sixth season, in a manner that may seem either gratuitous or in unison with the interconnectedness of the fictional world. For example, in "Ab Aeterno" (S06E09), the Black Rock, along with the gigantic wave that brought it on the island, is shown to be both the cause of the destruction of the Taweret statue (a mystery from the moment Sayid, Jin and Sun spotted its foot in "Live Together, Die Alone", S03E23\&24), and the last missing piece in the biography of enigmatic character Richard Alpert. Two birds, one stone. Everything is connected and explained, regardless of whether it was planned or improvised. And yet, one key piece of 
this puzzle is still missing, the one that may be partly responsible for the polarizing reception of the finale: the complete incompleteness of Lost's fictional world.

Here, as I am well aware that narratology, even in its more descriptive aspects, cannot be completely objective, I want to take a look at both the fictional world and the way the narrative presents it to the audience to better explain why even the very structure of the fictional world may play a part in Lost's ambiguous and open ending.

As Claire Cornillon explains in this very issue, Lost, along its six seasons, operates a kind of "generic sliding", going from a "robinsonade" to mystery, adventure, conspiracy thriller and science fiction ${ }^{47}$, before making a final, Jacobian turn and veering toward fantasy. Those generic considerations concern both the fictional world itself and the "texture" of the text, that is, the "exact form of expression, the original wording in which the motif appears in the literary text", as Lubomír Doležel puts it ${ }^{48}$. Genres have specific sets of imagery and motifs, they also have their own "wording"; they generate different expectations and call for specific reading strategies.

In the case of Lost, I would argue that the "Light" is never really given a definitive explanation or frame of interpretation on the fictional genres spectrum: because we only hear about it from characters in a fictional world full of conman and conwoman, liars, and deceivers; and because the generic sliding ends up superposing at least two reading strategies of the events, strategies than can either be perceived as conflicting or completing each other.

From an intradiegetic point of view, one has to admit all explanations about the nature of the Light may be suspicious. The only clear proof that it even exists is the intense electromagnetism it gives off: a danger that is given form in the end of season two, with the Swan Station imploding. The audience can link the electromagnetism to time travel since "Flashes Before Your Eyes" (S03E08), an episode flashing back to Desmond's traumatic experience when turning the failsafe key, seems to present them as functioning as a dynamic duo: Desmond unleashes the energy of the Swan Station and is propelled back in time instantaneously. Later plot developments allow the audience to link the "small pockets" of the Swan Station and the "Frozen Wheel" with the "Heart of the Island", and even other pockets around the globe (most notably in "316", S05E06, when Eloise Hawking explains how the Island moves).

On the one hand, the claim from Pierre Chang in "There's No Place Like Home, Part 2" (S04E13), that DHARMA scientists believe the Light to be "negatively charged exotic matter", may be seen as another ruse on the part of a show that is used to "deconstructing the very fabric of ideologies" and systematically destroys frames of interpretation one after the other ${ }^{49}$. Then again, Chang's claim could also be read, not as an attempt to apply a scientist frame to something indescribable, but as a scientific way of saying that it is ineffable: "exotic matter" simply means that something is not behaving according to the known laws of physics, and "negatively charged" is used to link the energy it gives off to the potential creation of wormholes, bringing with it the idea of time travel (one of the effects of the Light... unless the Light is time ${ }^{50}$ ). It has no more descriptive value than plain technobabble and fits in the science-fictional seasons four and five. I am not implying here that the audience will be able to decrypt Chang's hypothesis; but it is interesting to note that the writers were very careful not to give out anything. Chang's claims may not be a "false lead" in that they readily acknowledge the 
limits of human understanding of the universe, and the fear that comes with it (especially in season 5).

On the other hand, the Mother's description of the Light may seem to be the "ultimate answer", since it comes from a character that initially possesses authority over even the divine figure of Jacob, and because it is given at the end of the series, at the precise moment the most important answers and the last revelations are supposed to appear. Yet when, in "Across the Sea" (S06E15), she describes the Light as "life, death, rebirth" and as something present in every living thing in a small amount (again, one may think about time itself), she may very well be giving her subjective point of view, just as Chang gives his. As authoritative as she is, it is worth noting that the Mother came from a time when even the most basic natural events were the source of myths and legends. When Chang uses cautious, scientific terms, the Mother speaks in metaphors - just like Ben Linus and his "magic box".

41 Even if the "generic sliding" clearly plays on fantasy in the last season (I agree with Claire Cornillon here), this sliding could be perceived the other way around: since science fiction got in the mix during at least two seasons, the Light could be interpreted under the (I admit, overused) Third Law of writer Arthur C. Clarke: "Any sufficiently advanced technology is indistinguishable from magic". The island is the novum of the narrative, a "strange newness", following Darko Suvin's definition ${ }^{51}$; but if fantasy deals with "the impossible and the unexplainable", science fiction "regards everything as explicable", and even calls for a "culturally specific explanation ${ }^{52 "}$. Yet, the narrative never gives the complete details of the "alethic modalities" of the fictional world: what is possible, impossible or necessary in the fictional world ${ }^{53}$ - its natural laws. We will never know if we encountered magic or a phenomenon that can be explained by science - and the narrative seems to imply that it is not even a critical matter.

In an ironic turn of events, Jacob's metaphor of the island as a cork keeping the monster in is the most accurate, since the Heart of the Island really does contain... a giant stone cork. Notice how this metaphor, suggested by a character inside the fictional world, superposes with another one, as "The End" (S06E17) shows the candy machine scene after Desmond unplugs the cork and before Jack plugs it back in. The flashsideways reuniting Juliet and Sawyer is placed there by the writers in order to give a clue as to what is happening around the same time in the episode (but in different timeframes and even dimensions in the fictional world). The island is compared to both a very old bottle of wine (the blood of Christ) and a machine distributing candies to those who know its secret.

The series, especially in its sixth season, goes to great length to explain the function and effects of the Light: it allows one to time travel, it turns people into smoke monsters apart from those "vaccinated ${ }^{54 "}$ by constant exposure like Desmond - and it keeps the monster on the Island; also, it can be unplugged and then plugged back in, and "the candy just drops right in" as Juliet says. Function and effects of the Light are a necessary toolset to understand the stakes and the dangers that the characters have to master; but the nature of the Light - is it magic or an unknown scientific phenomenon? - does not matter for the characters. It has mattered for the theorist part of the audience ("what is it?"), and this is where the already fractured reception may have ruptured completely. The nature of the Light seems like a critical puzzle piece of the "what is the island?" major question that the plot left unanswered or, more precisely, left in a fluctuating state. The series remains voluntarily evasive and metaphorical, and submits two contradicting - or 
are they? - frames of interpretation, allowing for what I would call a quantum reading. There is no single way to understand the events in the fictional world or, more precisely, there are many ways to understand that the Light is something beyond the characters' (and possibly the viewers') grasp.

The Light at the Heart of the Island is something that transcends time, space and fictional genres. It is an area of the fictional world over which the audience will never have a definitive grasp, for it is ineffable. It thus derives from the incompleteness inherent to fictional worlds. But where Thomas Pavel described the equivalent of Doležel's "saturation" of the fictional world by picturing a circle of light surrounded by darker and darker areas ${ }^{55}$, Lost seems to take it the other way around, and this is why I have talked of a complete incompleteness for lack of a better terminology: this ultimate informational void around which the entire fictional world orbits is not pitch black. It is filled with a very bright light.

It is the incompleteness of fictional worlds (and by proxy, of our own world, never to be understood completely) suddenly made manifest, magnificent and transcendent, allowing the characters to finally find peace even if themselves may not understand everything that happened.

It is darkness turned into light.

\section{Crashing/Landing, Living/Dying}

Past the bamboo forest, there is one final place that, perhaps, was the catalyst for the more bitter "discourses of rejection": the revelation that the flashsideways were an undefined, shared afterlife dimension of the fictional world. You may notice that I am weighing every word here; I will get back to this, but first it is critical to acknowledge what the flashsideways did to the narrative and why they were so poorly received.

Just as overused as Clarke's Third Law, are comparisons to the Schrödinger's cat thought experiment, and musings on quantum mechanics. Yet, beyond science fiction stories specifically dealing with quantum effects applied to everyday life, the idea made its way into academia. Alexis Blanchet's work on "fictions quantiques", describing variations in different medias exploiting the same fictional world ${ }^{56}$ (for example, the superposition of the Marvel universe in comics and in the movies and TV series), may be linked to Sarah Hatchuel's work on superposition in a single work, especially in TV series, through dreams unveiling possible outcomes and playing with the narrative ${ }^{57}$. A new mode of complex narration at play in television shows such as the fractured timeline of Awake (NBC, 2012) or the dreams within dreams in The Sopranos (HBO, 1999-2007), quantum narration breaks the unity of a given fictional world as much as it breaks the fourth wall, revealing what was once hidden in a text, barely exploitable: the "possible texts" that didn't see the light of day ${ }^{58}$.

In its last season, Lost goes beyond dreams evoking possible outcomes to enter a complex, ambiguous space: the flashsideways. They initially appear as a consequence of Juliet detonating a hydrogen bomb in the Swan in 1977, in the hope of modifying the timeline and avoid the construction of the station, in which Desmond spent three years before inadvertently crashing Oceanic Flight 815 . Following the science fictional frame of interpretation of the previous seasons, one may think that the first scenes of LAX are happening in an alternate reality, a classic plot device of the science fiction genre, in line 
with what the characters were hoping to achieve at the end of season 5. Oceanic Flight 815 lands in LAX on schedule in 2004, and the island was apparently destroyed and submerged decades earlier in a cataclysmic event. But why would Desmond be on the plane? Is that new reality subject to the same eerie interconnectedness as the previous one?

This is only two of the many questions that the sixth season's flashsideways may bring to the viewer's mind, as they operate an intriguing "denarration", "a kind of narrative negation in which a narrator denies significant aspects of her narrative that had earlier been presented as given ${ }^{59}$." The series appears to negate the very incident that started the plot, while still navigating between the flashsideways and the main timeline, in which the characters stranded in 1977 are mysteriously sent back to 2007, having caused the Swan Incident they had tried to erase.

51 When "The End" revealed that all the characters were, in fact, living in an afterlife dimension - since they are all dead at the time of the flashsideways - the reception was mixed, to say the least. Sarah Hatchuel and Randy Laist, exploring the parallels between Lost and Shakespeare's The Tempest and other late romances in this issue of TV/Series, explain that the plays' receptions were similar in that they were all accused by critics of being confusing, and their endings of veering towards unwelcomed redemption, faith and transcendence, away from the tragedy and nihilism of both Shakespeare's early works and the first seasons of Lost, in which the characters suffer without hope of ever reaching inner peace. This refusal to accept an optimist, perhaps naïve and downright spiritual ending is on a par with the denigrating of feminized readings perceived by Rebecca Williams.

Equally problematic is the way the flashsideways seemed to confirm the undying "purgatory theory", sparked by the initial weirdness of the island post-crash, and lines such as Jack's "Three days ago we all died" (metaphorically...) in "Tabula Rasa" (S01E03). That the writers finally chose to rely on afterlife when constructing the flashsideways seemed to imply that perhaps the whole island was a purgatory in itself, that thinking "they were all dead" was not so far-fetched. Christian Shephard's confirmation to his son that "[...] I'm real. You're real, everything that's ever happened to you is real. All those people in the church...they're real too" is a clear nod to the audience that may have trouble understanding the - arguably complex - configuration of the flashsideways, a place where time has no meaning.

If I refuse to call the flashsideways purgatory or even a "shared dream", as Sarah Hatchuel and other critics call it, it is because I believe the flashsideways are presented in the same way as the Light by the narrative: as an ambiguous element whose nature is unclear, but whose function is more or less determined. When one observes the structure of the fictional world in the most objective way possible, keeping in mind that the onisland events are supposed to be actual events in the fictional world (and not the dog's dream, as Bart Simpson puts it $\left.{ }^{60}\right)$, then an intriguing chain of clues starts as soon as "Happily Ever After" (S06E11). In a process similar to his use of the failsafe key and subsequent time jumps in "The Constant" (S04E05), Desmond's consciousness (on-island) is propelled in the flashsideways by Widmore's machine - basically a giant magnet whose subtlety can only be seen as a reflexive wink to the audience. Since Desmond comes back to the island with a changed state of mind, one can assume he remembers the events he lived in the flashsideways, which is confirmed in "The End" by his telling to Jack: "You're 
in this place. You know, we sat next to each other on Oceanic 815. It never crashed. We spoke to each other. You seemed happy."

Add to this the fact that the flashsideways were initially presumed to be an alternate reality - meaning, another version of the fictional world existing alongside the first one and the traditional focus on a character per episode, and it may become clear that the narrative never "lied" since it presented the flashsideways as a world experienced by all the characters simultaneously. If it lied, it is by omission (just like Locke), forgetting to tell us that the characters... forgot they were dead. In a way, the sixth season behaves exactly as the afterlife castaways, only remembering in the end what came before.

The revelation of "The End" seemed to tip the balance, because the flashsideways may have been interpreted as a dream or a near death experience happening exclusively in Jack's mind, and thus invalidating what season six proposed (even if it still would have been an interesting twist of the narrative). Christian Shephard is also here to cast out all doubt and bring back lost sheep on the trail of clues indicating that the flashsideways are an undefined, shared afterlife dimension of the fictional world. "Dimension", because it seems to be a specific subset of the fictional world only accessible when one dies. "Afterlife" is a giveaway; "shared" underlines the communal experience lived by the afterlife castaways, each of them a conscious agent of the fictional world with a mental life and a memory - flashing back to their life down there - sharing this space they have allegedly created together because of their strong link (through romances, friendships, and family). "Undefined" because, while I acknowledge the strong religious texture of the episode, with its church and bright light and the very name of Jack's father, once again the narrative seems very ambiguous on the nature of this shared dimension, emphasizing its function to create emotion.

56 My point here, if there ever was one, is that both the Light's and the flashsideways' natures are never completely explained - and the narrative emphasizes the pointlessness of such an explanation by superposing different frames of interpretation - but their functions were underlined, sometimes in a very straightforward and didactic way, to make sure the audience could understand the stakes faced by the characters. Like the Light, the flashsideways can be seen as a shared dream, purgatory, or a science-fictional dimension created by the consciousness of the characters - all plausible interpretations because the last episodes emphasized the basic characteristics of this undefined dimension without reducing (maybe slightly guiding) the viewer's interpretative potential.

\section{A very bright light}

57 At the end of "The End", the mystery box is finally opened but, from a narratological point of view, it still contains what made it so mysterious in the first place: possibilities. What the viewers have made of it says a great deal about how they approach fiction, and even the real world itself. I do not imply that the "theorist fans" were wrong; but I would argue - as a former theorist fan myself - that the text veers away from any unilateral, one-dimensional "theory of everything". The biographical trajectory of Jack, from "man of science" to "man of faith", says it all: maybe the key to appreciate Lost, the key found by the "characters fans", was to keep a mind open to possibilities - plural intended. Good or bad, right or wrong, Cuse and Lindelof tried a bold move in the television context of the 2000's: they experimented with the limits of fiction itself. 


\section{BIBLIOGRAPHY}

ABBOTT Stacey, "How Lost Found Its Audience: The Making of a Cult Blockbuster", in Reading Lost: Perspectives on a Hit Television Show, ed. Roberta Pearson, Londres I. B. Tauris, 2009 [p. 9-26].

ASKWITH Ivan, “'Do you even know where this is going?' Lost viewers and narrative premeditation", in Reading Lost: Perspectives on a Hit Television Show, ed. Roberta Pearson, London, I. B. Tauris, 2009, [p. 159-180].

BARONI Raphaël, La Tension narrative : Suspense, curiosité et surprise, Paris, Seuil, 2007.

BENNETT Tara, Showrunners: The Art of Running a TV Show, London, Titan Books, 2014.

BLANCHET Alexis, "L'adaptation de films de cinéma en jeux vidéo : des synergies intermédiatiques aux fictions quantiques", Questions de communication, série actes 8/2010, January 2010 [p. 205-222].

BORDWELL David, Making Meaning, Cambridge, London, Harvard University Press, 1989.

CARROLL Noël, “Narrative Closure”, Philosophical Studies, n¹35, 2007 [p. 1-15].

DOLEZEL Lubomír, Heterocosmica: Fiction and Possible Worlds, Baltimore, London, John Hopkins University Press, 1998.

ESCOLA Marc, "Changer le monde : textes possibles, mondes possibles", in La Théorie littéraire des mondes possibles, ed. Françoise Lavocat, Paris, CNRS Éditions, 2010 [p. 243-258]

ESCOLA Marc, "Le clou de Tchekhov. Retours sur le principe de causalité regressive", Fabula, 2010.

FAVARD Florent, La Promesse d'un dénouement : énigmes, quêtes et voyages dans le temps dans les séries télévisées de science-fiction contemporaines, Doctoral thesis supervised by Pr. Pierre Beylot, Bordeaux Montaigne University, presented November 6th, 2015.

_-_. "The Yellow umbrella syndrome: Pledging and delaying narrative closure in How I Met Your Mother", GRAAT Anglophone studies, \#15, April 2014 [p. 24-49].

GERVAIS Bertrand, “Lecture : tensions et régies”, Poétique, n89, 1992 [p. 105-125].

“Lectures de récits et compréhension de l'action”, Recherches Sémiotiques, vol. 9, 1989 [p. 151-167].

GRAY Jonathan, Show Sold Separately: Promos, Spoilers, and Other Media Paratexts, New York, London, NYU Press, 2010.

GRAY Jonathan et Jason MITTELL, "Speculation on spoilers: Lost fandom, narrative consumption and rethinking textuality”, Particip@tions, n¹, vol. 4, 2007.

TV/Series, Hors séries 1 | 2016 
HATCHUEL Sarah, Rêves et séries américaines, la fabrique d'autres mondes, Aix-en-Provence, Rouge profond, 2015.

--_. Lost : Fiction vitale, Paris, PUF, 2013.

JENKINS Henry, Convergence Culture: Where Old and New Media Collide, London, New York, NYU Press, 2006 (revised edition, 2008).

LAVERY David, "Is Lost Science Fiction?", in The Essential Science Fiction Television Reader, ed. J. P. Telotte, Lexington, University Press of Kentucky, 2008 [p. 283-298].

MARTIN Martial, "La situation instable du public de Lost sur internet : entre licence et contrainte”, Réseaux, vol. 29, n¹65, 2011 [p. 165-180].

MENDLESOHN Farah, Edward James, A Short History of Fantasy, London, Middlesex University Press, 2009.

MITTELL Jason, Complex TV: The Poetics of Contemporary Television Storytelling, New York, London, New York University Press, 2015.

.Playing for Plot in the Lost and Portal Franchises", Eludamos, Vol. 6, n¹, 2012, [p. 5-13].

"Previously on: Prime time serials and the mechanics of memory", in Intermediality and storytelling, ed. Marina Grishakova and Marie-Laure Ryan, Berlin, Walter de Gruyter, 2010 [p. 78-98].

."Lost in a great story: Evaluation in Narrative Television (and Television Studies)", in Reading Lost: Perspectives on a Hit Television Show, ed. Roberta Pearson, London, I. B. Tauris, 2009 [p. $120-138]$.

MOUSOUTZANIS Aris, “'Enslaved by Time and Space’: Determinism, Traumatic Temporality, and Global Interconnectedness”, in Looking for Lost: Critical Essays on the Enigmatic Series, ed. Randy Laist, Jefferson, London, McFarland, 2011 [p. 43-58].

PAVEL Thomas, Univers de la fiction, Paris, Éditions du Seuil, 1988.

PEARSON Roberta, "Chain of Events: Regimes of Evaluation and Lost's Construction of the Televisual Character", in Reading Lost: Perspectives on a Hit Television Show, ed. Roberta Pearson, London, I. B. Tauris, 2009 [p. 139-158].

RICHARDSON Brian, "Denarration in Fiction: Erasing the Story in Beckett and Others", Narrative, vol. $9, n^{\circ} 2$, mai 2001 [p. 168-175].

RYAN Marie Laure, “Cheap plot tricks, Plot Holes, and Narrative Design “, Narrative, vol. 17, n¹, 2009 [p. 56-75].

SUVIN Darko, "Estrangement and Cognition", reprinted in Speculations on speculation: Theories of Science Fiction, ed. James Gunn, Matthew Candelari, Laham, Toronto, Oxford, The Scarecrow Press, 2005 [p. 23-35].

WILLIAMS Rebecca, Post-Object Fandom: Television, Identity and Self-narrative, New York, London, Bloomsbury, 2015.

\section{NOTES}

1. Stacey Abbott, "How Lost Found Its Audience: The Making of a Cult Blockbuster", in Reading Lost: Perspectives on a Hit Television Show, ed. Roberta Pearson, London, I. B. Tauris, 2009 [p. 9-26]. 2. I would like to thank Claire Cornillon and Sarah Hatchuel for their vital input. 
3. Ryan acknowledges "exceptions" such as Claude Bremond, Thomas Pavel or Emma Kafalenos, and of course herself, as her body of work may testify. See Marie Laure Ryan, "Cheap plot tricks, Plot Holes, and Narrative Design", Narrative, vol. 17, n¹, 2009, p. 73 [p. 56-75]

4. Lubomír Doležel, Heterocosmica: Fiction and Possible Worlds, Baltimore, London, John Hopkins University Press, 1998, p. 20-21.

5. David Bordwell, Making Meaning, Cambridge, London, Harvard University Press, 1989, p. 3.

6. Ibid., p. 9.

7. Bertrand Gervais, "Lectures de récits et compréhension de l'action", Recherches Sémiotiques, vol.

9, 1989 [p. 151-167]; available online: http://www.vox-poetica.org/t/pas/bgervais.html [accessed September 2016]. See also Bertrand Gervais, “Lecture : tensions et régies”, Poétique, $\mathrm{n}^{\circ}$ 89, 1992 [p. 105-125]. Both Gervais and Bordwell acknowledge that the first-time interpreter of a narrative and an interpreter already familiar with a given text can both practice comprehension and/or interpretation, progression and/or compréhension: these modes of reading are not bound to the familiarity with the text.

8. Jason Mittell, Complex TV: The Poetics of Contemporary Television Storytelling, New York, London, New York University Press, 2015, p. 18.

9. Noël Carroll, "Narrative Closure”, Philosophical Studies, n¹35, 2007, p. 2 [p. 1-15].

10. Ibid., p. 5.

11. Ibid., p. 2-3.

12. Jason Mittell, "Previously on: Prime time serials and the mechanics of memory", in Intermediality and storytelling, ed. Marina Grishakova and Marie-Laure Ryan, Berlin, Walter de Gruyter, 2010, p. 81 [p. 78-98].

13. See Raphaël Baroni, La Tension narrative : Suspense, curiosité et surprise, Paris, Seuil, 2007.

14. Henry Jenkins, Convergence Culture: Where Old and New Media Collide, London, New York, NYU Press, 2006 (revised edition, 2008).

15. Jason Mittell, "Lost in a great story: Evaluation in Narrative Television (and Television Studies)", in Reading Lost: Perspectives on a Hit Television Show, ed. Roberta Pearson, London, I. B. Tauris, 2009, p. 128-130 [p. 120-138].

16. See for example Sarah Hatchuel, Lost : Fiction vitale, Paris, PUF, 2013, p. 25.

17. If Lindelof himself is to be believed, he quoted this anonymous tweet and some more to Josef Adalian. See Josef, Adalian "Damon Lindelof Shares the Meanest Tweets Lobbed His Way", Vulture , August $1^{\text {st }}, 2010$, http://www.vulture.com/2010/08/twitter.html [accessed September 2016].

18. Damon Lindelof, as always, retweeted many of these, and a selection can still be found on fansite Fuck Yeah Lost at http://fuckyeahlost.com/post/62730757076/lots-of-whining-on-twitterlast-night [accessed September 2016].

19. See Rebecca Williams, Post-Object Fandom: Television, Identity and Self-narrative, New York, London, Bloomsbury, 2015, p. 113 and following.

20. Although Lindelof used his departure as an advertising stunt, since October $14^{\text {th }}$ is the date of "the Departure" in his next series The Leftovers (HBO, 2014-2017).

21. Rebecca Williams, op. cit., p. 113.

22. Ibid., p. 119.

23. Ibid.., chapter 4, pages 93-100 for the fans; chapter 5, pages 113-122 for the anti-fans.

24. Still available at http://lostislandforum.free.fr/forum/.

25. See Florent Favard, La Promesse d'un dénouement : énigmes, quêtes et voyages dans le temps dans les séries télévisées de science-fiction contemporaines, Doctoral thesis supervised by Pr. Pierre Beylot, Bordeaux Montaigne University, presented November 6th, 2015, section III.2.2.3, p. 535, available online: https://tel.archives-ouvertes.fr/tel-01301614.

26. Roberta Pearson, "Chain of Events: Regimes of Evaluation and Lost's Construction of the Televisual Character", in Reading Lost: Perspectives on a Hit Television Show, ed. Roberta Pearson, London, I. B. Tauris, 2009, p. 143-144 [p. 139-158]. 
27. Ivan Askwith, “'Do you even know where this is going?' Lost viewers and narrative premeditation", in Reading Lost: Perspectives on a Hit Television Show, ed. Roberta Pearson, London, I. B. Tauris, 2009, [p. 159-180].

28. Jason Mittell, "Playing for Plot in the Lost and Portal Franchises", Eludamos, Vol. 6, n 1,2012 , [p. 5-13]

29. Jonathan Gray, Jason Mittell, "Speculation on spoilers: Lost fandom, narrative consumption and rethinking textuality”, Particip@tions, n¹, vol. 4, 2007, available online: http:// www.participations.org/Volume\%204/Issue\%201/4_01_graymittell.htm [accessed September 2016].

30. Martial Martin, "La situation instable du public de Lost sur internet : entre licence et contrainte ", Réseaux, vol. 29, n¹65, 2011, p. 170-171 [p. 165-180].

31. For a detailed analysis of the latter, see Florent Favard, "The Yellow umbrella syndrome: Pledging and delaying narrative closure in How I Met Your Mother", GRAAT Anglophone studies, \#15, April 2014 [p. 24-49].

32. In an unrelated reception study of the series finale of Fringe on the microblogging site Tumblr, I found out that on 82 posts thanking an author entity, 32 mentioned "the writers", 31 "Abrams", and 19 "J. H. Wyman", at the time current showrunner of season five. Results, which were measured in a total pool of 4191 posts in the 24 hours following the airing of the series finale, may have been influenced by some posts liveblogging a party at Bad Robot, and a special message thanking the fans, written by Abrams, that was reblogged many times over furthermore illustrating the importance of Bad Robot and Abrams in production discourse, in turn influencing fan discourse. Results were initially presented in Florent Favard, «La Fin de la série Fringe : $24 \mathrm{~h}$ de publications sur le réseau de microblogging Tumblr», doctoral seminar, AFECCAV, September $7^{\text {th }}, 2013$, INHA, Paris.

33. See the section on Abrams in Jonathan Gray, Show Sold Separately: Promos, Spoilers, and Other Media Paratexts, New York, London, NYU Press, 2010, p. 135 and following.

34. Ibid., p. 136.

35. For a detailed analysis of what "mythology" means in television writing, see for example Florent Favard, La Promesse d'un dénouement (op. cit.), chapter I.2, p. 101, available online: https:// tel.archives-ouvertes.fr/tel-01301614.

36. Damon Lindelof, keynote at the 2011 New York Television Festival. Audio from the keynote can be found at http://darkufo.blogspot.fr/2011/09/audio-from-damon-lindelof-chat-atnytvf.html [at 24:30].

37. See J. J. Abrams, «The Mystery Box », TED conference, March 2007, https://www.ted.com/ talks/j_j_abrams_mystery_box.

38. See for example 医Aris Mousoutzanis, “"Enslaved by Time and Space': Determinism, Traumatic Temporality, and Global Interconnectedness", in Looking for Lost: Critical Essays on the Enigmatic Series, ed. Randy Laist, Jefferson, London, McFarland, 2011 [p. 43-58].

39. Ivan Askwith, op. cit., p. 172-173 [p. 159-180].

40. Jason Mittell, Complex TV (op. cit.), p. 24-25.

41. I translate, Marc Escola, "Le clou de Tchekhov. Retours sur le principe de causalité regressive", Fabula, 2010, available online: http://www.fabula.org/atelier.php? Principe_de_causalite_regressive [accessed September 2016).

42. Javier Grillo-Marxuach, "The Lost Will and Testament of Javier Grillo-Marxuach", March $24^{\text {th }}$, 2015, available online : http://okbjgm.weebly.com/lost/the-lost-will-and-testament-of-javiergrillo-marxuach, p. 21.

43. Javier Grillo-Marxuach, op. cit., p. 42.

44. Tara Bennett, Showrunners: The Art of Running a TV Show, London, Titan Books, 2014, p. 195.

45. See J. J. Abrams, “The Mystery Box”, TED conference, March 2007, https://www.ted.com/ talks/j_j_abrams_mystery_box. 
46. See J. J. Abrams, “The Mystery Box”, TED conference, March 2007, https://www.ted.com/ talks/j_j_abrams_mystery_box.

47. This generic doubt was already looming back in the first seasons, as exemplified by David Lavery, "Is Lost Science Fiction?", in The Essential Science Fiction Television Reader, ed. J. P. Telotte, Lexington, University Press of Kentucky, 2008 [p. 283-298] - a question that the author left unanswered.

48. In which the "motif" is an elementary, conventional narrative micro-structure such as a murder, the fall of night or... a plane crash. See Lubomír Doležel, op. cit., p. 35-36.

49. See Sarah Hatchuel, op. cit., p. 84-88.

50. The "pseudo-canon" - or as the Lostpedia wiki calls it, "deuterocanon" - ARG The DHARMA Initiative Recruiting Project, launched between seasons 4 and 5, began with an intriguing video showing Pierre Chang addressing the viewers, demonstrating an eerie knowledge of nowadays events, and possibly talking with Faraday. Chang has a peculiar line: "Time is not of the essence. It is the essence". See http://lostpedia.wikia.com/wiki/DHARMA_booth_video.

51. Darko Suvin, "Estrangement and Cognition", reprinted in Speculations on speculation: Theories of Science Fiction, ed. James Gunn, Matthew Candelari, Laham, Toronto, Oxford, The Scarecrow Press, 2005, p. 24-26 [p. 23-35].

52. Farah Mendlesohn, Edward James, A Short History of Fantasy, London, Middlesex University Press, 2009, p. 3.

53. Lubomír Doležel, op. cit., p. 114-120.

54. Which may bring us back to the "sickness" that Desmond's vaccines are supposed to prevent in season 2.

55. Thomas Pavel, Univers de la fiction, Paris, Éditions du Seuil, 1988, p. 120.

56. See for example Alexis Blanchet, "L'adaptation de films de cinéma en jeux vidéo : des synergies intermédiatiques aux fictions quantiques", Questions de communication, série actes 8/2010, January 2010 [p. 205-222].

57. See Sarah Hatchuel, Rêves et séries américaines, la fabrique d'autres mondes, Aix-en-Provence, Rouge profond, 2015, especially the chapter on The Sopranos, p. 97-124.

58. A variation on possible world theory applied to fiction, possible texts theory is explored in Marc Escola, "Changer le monde : textes possibles, mondes possibles", in La Théorie littéraire des mondes possibles, ed. Françoise Lavocat, Paris, CNRS Éditions, 2010 [p. 243-258].

59. Brian Richardson, "Denarration in Fiction: Erasing the Story in Beckett and Others", Narrative , vol. 9, n², mai 2001, p. 168 [p. 168-175].

60. In the opening credits of "Judge Me Tender" (S21E23), first aired at the same time as "The End".

\section{ABSTRACTS}

This paper intends to question certain narrative particularities of TV series Lost, taking into account its polarizing, if not fractured, reception. Building on the production and reception of the series (most notably the conception of a long term plot making a "closure pledge", and authorial discourse orienting a teleological reading), this paper follows both the possible worlds theory applied to fiction and Marie-Laure Ryan's philosophy of "storyology", in order to analyse the impact of Abrams' "mystery box" concept on audience readings of the series, and the generic 
superposition of ambiguous narrative elements such as the Heart of the Island and the flashsideways.

Cet article entend s'interroger sur quelques particularités narratives de la série Lost, à l'aune de sa réception polarisée, voire fracturée. Prenant en compte le contexte de production et de réception de la série (notamment, la problématique de l'écriture d'une intrigue «macroscopique » faisant la « promesse d'un dénouement » sur le long terme, et les discours des instances auctoriales orientant une lecture téléologique), cet article s'inspire de la théorie des mondes possibles appliquée à la fiction et de la storyology explorée notamment par Marie-Laure Ryan, pour analyser l'impact du concept de «boîte mystère » proposé par J. J. Abrams sur la lecture de l'intrigue par le public, et la superposition générique des cadres d'interprétations des éléments ambigus que sont le Cœur de l'île et les flashsideways.

\section{INDEX}

Mots-clés: Lost, narration, superposition, fin, clôture

Keywords: Lost, narration, superposition, ending, closure

\section{AUTHOR}

\section{FLORENT FAVARD}

Florent Favard est Docteur en Études Cinématographiques et Audiovisuelles à l'Université Bordeaux Montaigne. Il travaille sur la complexité narrative des séries télévisées, les genres de l'imaginaire et le transmedia storytelling, dans une perspective narratologique contextualiste et transmédiatique.

Florent Favard holds a PhD in Cinema and Audiovisual Studies from Bordeaux Montaigne University. He works on TV series narrative complexity, science fiction and fantasy genres, and transmedia storytelling, within the field of transmedial narratology. 